\title{
The Achievement of National Education Standards of The Private Islamic Senior High School (Madrasah Aliyah) in West Lombok During the Period of Covid-19 Pandemic
}

\author{
Anita Yulia* \\ Educational Administration Post Graduate Program \\ University of Mataram \\ Mataram, Indonesia \\ anitayulia8787@gmail.com \\ Dadi Setiadi \\ Educational Administration Post Graduate Program \\ University of Mataram \\ Mataram, Indonesia \\ setiadi_dadi@unram.ac.id
}

\author{
Hamid Syukrie ZM \\ Educational Administration Post Graduate Program \\ University of Mataram \\ Mataram, Indonesia \\ hamidsyukriezm@unram.ac.id \\ F Fahruddin \\ Educational Administration Post Graduate Program \\ University of Mataram \\ Mataram, Indonesia \\ fahruddin.fkip@unram.ac.id
}

\begin{abstract}
The attainment of national education standards for Private Islamic Senior High schools in rural areas is a serious matter due to limited resources. This research aims to analyze the achievement of national education standards of process, staff and teacher, and school management in Private Islamic Senior High School. This study used a qualitative approach, data were collected through interviews, documents, observations and analyzed descriptively. The results showed that Private Islamic Senior High School in general met national standards through an evaluation of the external quality assurance system. Competency standards of process, staff and teacher, and school management are not achieved well because they are influenced by many other factors, including the fulfillment of facilities and educator standards during the COVID-19 pandemic despite peer online mentors. The fulfillment of these three standards cannot be carried out according to the challenge because students are learning from home and face problems related to the internet connection. As for management and financial standards, there were slight differences in Private Islamic Senior High School with the intervention from the foundation. The standards of educators and education personnel have not been thoroughly fulfilled due to the limited number of certified staff both teaching and education personnel. The achievement of national education standards in Private Islamic Senior High School still needs to be improved about process standards, management and teacher also the educational staff.
\end{abstract}

Keywords: education national standard, private Islamic senior high school

\section{INTRODUCTION}

The world of education always experiences very rapid reforms at the level of policies and regulations. However, on the ground for Private Islamic Senior High School (Madrasah Aliyah), it is very difficult to adjust these policies. The Public Islamic Senior High School that are included in the National Education System (NES) of Indonesia must be able to keep up with policy changes and the first thing is to meet national education standards first. This provision of fulfillment for the school is a challenge to be able to progress according to the public school's budget. Hence, efforts are needed to make the Islamic School meet national education standards more specifically during a pandemic. Opportunities for advancing the Islamic Senior High School can improve its qualities to meet national education standards and other policies. Hence, if the quality can be increased, the school will be able to cover the eight NES.

However, the condition of Private Islamic Senior High School, especially in West Lombok, varied widely in their ability to meet national education standards and they are usually built with the reliance on community participation. In general, Private Islamic Senior High Schools in rural areas are facing various challenges due to several teacher resources are not supported by their teaching qualifications (especially for general subjects), lack of learning infrastructure, and management constraints. These constraints are mainly related to how to maximize the empowerment and development of existing resources, as well as the ability to find new, innovative sources. Also, the implementation of education refers to the lack of implementation of NES in planning, implementing, and supervising education, which aims to guarantee the quality of education, to educate the nation's life, and to shape the character of a dignified national civilization[1].

The NES should be used as a reference in mapping the quality profile of the Private Islamic Senior High School. It includes the Standards for Graduate Competencies, Content, Process, Educators and Education Staff, Facilities and Infrastructure, Management, Financing, and Educational Assessment. To measure the achievement of these national standards, the team of School Accreditation Institution usually carries out an external quality assurance assessment. Recognition of the accreditation rank for each education unit 
is manifested in the form of a school/madrasah accreditation certificate. The implementation of accreditation is expected to be able to encourage or create a conducive atmosphere for the achievement of NES and improve the quality of education and provide direction for self-evaluation and sustainable efforts. Accreditation also, an encouragement for educational units to continue to strive to achieve the expected quality so that indirectly it can guarantee the quality of education [2]. In addition, four standards are still very low in achievement, namely standards of facilities and infrastructure, process standards, competency standards of graduates, and standards of educators and educational staff [3]. Based on another study, the data on the results of accreditation on the eight standards of the accredited madrasah on the average of graduate competency standards is still low compared to other standards. This condition is caused by several factors including compliance with process standards, educators and education management.

The NES functioned as a basis for planning directed and sustainable following the demands of local, national, and global changes. To guarantee and control the quality of education according to the NES, evaluation, accreditation, and certification are carried out. Furthermore, NES regulates the plan, direct and manage education in a sustainable manner following the changes in local, national, and global scales. The existence of NES is expected to guarantee the quality of education in Indonesia in a broad sense. Thus, the fulfillment of the national education standards of an educational unit can be used as a reflection regarding the quality of the related education unit. Therefore, the main step for private madrasah is to have a program to be able to fulfill the minimum education standards maximally to improve the quality of education in general, especially the competence of graduates. The fulfillment of national education standards in a private madrasah in rural areas has not been able to fulfill the maximum, while the fulfillment is the basis that must be met to improve quality. Based on the above description, it is necessary to conduct a study on the fulfillment of national standards focused on process standards and standards for educators and education personnel and management for Private Islamic Senior High School in rural areas of Narmada District, West Lombok.

\section{METHODS}

This research uses a qualitative method with a case study that aims to describe the data in words/descriptions and this explanation is directed to its original condition [4] meaning that there is no manipulation on the data or the data is left following the original in the field. The research approach is directed at these settings and individuals holistically and (intact). The research data were obtained through interviews with the principal of the Private Islamic Senior High School, curriculum's affairs department, students' affairs department, and public relations staff and teachers; observation, and review of the school's documents.

Furthermore, the data analysis process begins by examining all available data from various sources, namely interviews, observations that have been written down such as in field notes, documents, pictures, photos, and so on. The results of data collection need to be reduced (data processing) starting from editing and coding. Then the final stage of data analysis by checking the validity of the data using interactive analysis techniques developed by Miles and Huberman.

\section{RESULTS AND DISCUSSION}

\section{A. Results}

The implementation of the Standard Process following the data obtained does not meet what is billed as a whole from the learning process standard, whereas when viewed from the readiness of the teaching staff in preparing the learning process in the form of a syllabus, the new lesson plan is following the format of the national education quality standard. However, if it is examined from the quality of the content, it is not good according to the standard which is reflected in the lesson plans related to the learning process, it has not comprehensively fulfilled the bill of the learning process. Including the interaction in learning between educators and students, some educators are not skilled in how to plan and carry out learning following the provisions of the standard process, especially in stimulating students in encouraging motivation, interest, and serious attention in developing and mastering learning materials. In addition, in the context of the COVID-19 pandemic, the learning process cannot be carried out properly coupled with the learning from a home policy where the abilities of students vary greatly, especially with the ownership of hardware and being able to have an internet connection, including collaboration with their children in directing their children to learn well from home. Although such conditions have been implemented by the madrasah, a teacher visit program to accessible student residences, students who are far away are asked to report daily activities including forming a peer mentoring team where some students become mentors to help study at home through communication with some media. However, the results are still not as expected, this is difficult for the madrasah to control because many factors affect students.

a. Assessed from the fulfillment of professional certificates as is required in Standard of Teachers and Education Staff, it was found that not all personnel have professional certificates. The results show that the standard of new educators who already have educator certification reaches $65 \%$, while new teaching personnel reaches $45 \%$. It means, there is a lack of educators and education personnel to attend participant training or seminars to increase professionalism as educators and educational staff. This is also due to limitations in getting the opportunity to take part in teacher professional education for almost all subjects. However, schools and foundations have reported these conditions to the relevant agencies so that they can gradually provide opportunities for teachers to be able to take part in professional education for education and educators so that in the next few years the certification requirements for the two workers can be fulfilled.

b. Management standards look at the data obtained from the field that in general this administration has been fulfilled but in practice, it has not been effective, due to the lack of discipline of educational personnel in carrying out their duties as well as control and supervision have not been carried out properly from the 
leadership. As a result, it is necessary to make efforts to fill in the required data and information, if the data and information are needed as a report. Management in madrasah education units is not the same as public schools, because in madrasah management there are foundation policies that must be followed by madrasah management so that all management carried out by the Head of Private Islamic Senior High School must be with the permission of the foundation leadership and provide explanations related to the management of all resources in the Private Islamic Senior High School, including learning that from time to time is always experiencing developments related to processes and other needs that can support the improvement of the quality of learning management in the classroom and outside the classroom.

\section{B. DISCUSSION}

Standardization of education has a very significant impact on improving the quality of Private Islamic Senior High School and. become the direction and reference for a madrasah to commit to quality improvement. Fulfillment of these standards will make the quality of Private Islamic Senior High School continue to improve and have an impact in maximizing the fulfillment of NES. It will also be able to increase the well-managed internal quality assurance system, routine internal quality audits, and positive response to the needs of parents. It leads to the enhancement of Private Islamic Senior High School's competitiveness.

The standard of the education process in Private Islamic Senior High School needs to be improved. It is including the learning process where teachers must use a participatory learning model. Although the students might not be familiar with the learning model on its initial implementation, studies showed that it enables students to enjoy their learning process and reduce their bored feeling. Learning occurs in communication from various directions. In addition, democratization in learning occurs openly and all students are allowed to dare to ask questions, express opinions, and argue [5]. In this learning, teachers must be skilled in using various online media, integrating multimedia in the classroom, including allowing students to enhance academic and social skills as they communicate and share information, organize their ideas, and express opinions while preparing a project or conducting. research through online experience [6], so that students can more easily understand what to master.

In the context of learning during the pandemic, students can take part in learning using various sources which need to be supported by the required facilities. Therefore, the madrasah needs to plan well how the fulfillment of infrastructure that can support online learning optimally, and how the madrasah can guarantee quality through the internal madrasah quality assurance team. In addition, madrasahs can take advantage of the results of the assessment of the fulfillment of education standards to ensure that the quality of madrasah can be utilized properly, including what parts need to be improved through coordination between madrasahs and local governments. The accreditation tool contains an instrument component based on eight indicators of national education standards [7]. Another thing is that activities related to content standards, processes standards, and graduation standards must be supported by the madrasah and foundations through the head of the madrasah. This includes developing teaching materials that are packaged with various methods, strategies, and approaches that cannot be separated from three domains, namely cognitive, affective and psychomotor and all transformed knowledge must be strived to embody in shaping the character or attitude of students [8].

The standards of educators and education personnel still need to be increased regularly so that in the coming years all of them have met. In terms of teacher standards, teachers who do not meet the standards can go through the official channels to attend undergraduate education, and regularly participate in subject teacher organization (MGMP)'s activities [9], seminars, training, or training under the madrasah quality improvement program [10]. Also, the teacher should be able to apply various learning methods and strategies and make students not get bored quickly in learning where students are more involved while the teacher is only a facilitator [8]. To improve teacher performance to be optimal, it needs to be integrated with school components, including school principals, school culture/climate, teachers, employees, and students. Teacher performance is an inseparable part of a system starting from input, process, and output, to achieve the goals of an educational institution [11]. Related to this, several important factors can affect teacher performance in carrying out their duties, including leadership of the principal, school culture/climate, expectations, and beliefs of school personnel.

In management standards, it is necessary to pay attention to aspects of improving the quality of education by clarifying the vision, mission, use of electronic media, community involvement, teachers, students, and the government in terms of managing the quality of education [12]. In the management of education, there are four functions, which include planning, organizing, directing, monitoring, and developing. Issues related to education management in general, there are four main problems in education in Indonesia, namely the quality of education, expansion, and distribution of quality education services, relevance, effectiveness, and efficiency [13]. Educational unit leaders must be skilled in transforming a quality culture so that members of the education unit participate actively, so that the institution experiences changes in a positive direction, the head of the madrasah continues to transform his innovative ideas at every opportunity, such as in official or non-formal meetings either directly. or not and the principal should always provide a positive understanding and appreciation to school students. This makes madrasa residents always try and strive to be able to have a positive influence on the institution [14]. In addition, the fulfillment of Minimum Service Standards (SPM) needs to be a concern of Private Islamic Senior High School's leaders because it is closely related to NES which are both a measure of the quality of Private Islamic Senior High School that support each other, where SPM is sought to fulfill, especially by local governments, to be further improved to meet and even exceed NES [15].

The implementation of quality compliance by Private Islamic Senior High School to improve their performance is carried out in stages in meeting 8 NES in the implementation of teaching and learning processes and management to fulfill the standards for Graduate Competencies, Content, Process, 
Educators and Education Staff, Facilities and Infrastructure, Management, Financing, and Educational Assessment [16]. Also, the quality assurance that is carried out internally by Private Islamic Senior High School must be controlled and audited through accreditation activities so that it can maintain and improve the quality of Private Islamic Senior High School [17].

\section{CONCLUSION}

Fulfillment of national standards as a whole, including good, process standards and standards for teaching and management educators, need to be continuously improved for the fulfillment of standards gradually starting from all standards that support the learning process standards which are very influential in achieving the competency standards of graduates. For this fulfillment, it has received support from the government and support for community participation. The achievement of national education standards in Private Islamic Senior High School needs to be improved especially in terms of the process, management, and educational teaching staff's standards.

\section{ACKNOWLEDGMENT}

We express our deepest gratitude to the Chancellor of UNRAM for supporting research costs and to the Head of Madrasah Aliyah and his staff for all assistance and support during the research.

\section{REFERENCES}

[1] Hasbi, "Peningkatan Mutu Pendidikan Madrasah Dalam Sistem Pendidikan Nasional Di Kota Palopo Tahun 2011-2012," J. Diskurs. Islam, vol. 1, no. 3, 2013.

[2] A. A. R. Awaludin, "Akreditasi Sekolah Sebagai Suatu Upaya Penjaminan Mutu Pendidikan di Indonesia," J. SAP, vol. 2, no. 1, 2017.

[3] F. Alawiyah, "Standar Nasional Pendidikan Dasar dan Menengah National (Standards of Primary and Secondary Education)," Aspirasi, vol. 2, no. 1, 2017.

[4] J. W. Creswell, "Educational Research (Planning, Conducting, and Evaluating Quantitative and Qualitative Research," Third Ed., 2008.

[5] A. S. Anwar, "Peningkatan Mutu Pendidikan Pada Madrasah Aliyah Model MAN 2 Kota Serang Provinsi Banten," Al Tanzhim J. Penelit. Manaj. Pendidik., vol. 1, no. 1, 2018.

[6] A. Alismail and P. McGuire, "Century Standards and Curriculum: Current Research and Practice," J. Educ. Pract., vol. 6, no. 6, 2015.

[7] Haifaturrahmah, "Analisis Pencapaian 8 Komponen Standar Akreditasi SD/MI di Kota Mataram,” J. Elem., vol. 1, no. 1, 2018.

[8] S. M. M. I. Abdi, "Implementasi Standar Nasional Pendidikan Pada Sekolah-Sekolah Unggulan di Samarinda," Fenomena, vol. 9, no. 1, 2017.

[9] M. Sholeh, "Kajian Kritis Tentang Standar Nasional Pendidikan (SNP)," Al-Tanzim, vol. 1, no. 1, 2017.

[10] H. Anwar, "Standar Pengelolaan Pendidikan Dalam Perspektif Pengelolaan Madrasah Aliyah Swasta," TADBIR J. Manaj. Pendidik. Islam, vol. 5, no. 1, 2017.

[11] M. Fadhli, "Manajemen Peningkatan Mutu Pendidikan," TADBIR J. Stud. Manaj. Pendidik., vol. 1, no. 2, 2017.

[12] M. 2013 Arif, "Manajemen Madrasah Dalam Upaya Peningkatan Mutu Pendidikan Islam,” Epistemé, vol. 8, no. 2, 2013.

[13] M. F. Haq, "Analisis Standar Pengelolaan Pendidikan Dasar dan Menengah," Evaluasi, vol. 1, no. 1, 2017.

[14] dan A. D. W. S. Aminah, "Membangun Budaya Mutu Di Madrasah Unggul (Studi Kasus di MAN 1 Jember dan MA Unggulan Nurul Islam Jember)," Eval. J. Manaj. Pendidik. Islam, vol. 3, no. 1, 2019.
[15] J. Damanik, "Keterkaitan Standar Pelayanan Minimal (SPM) Dengan Standar Nasional Pendidikan (SNP)," JDP, vol. 10, no. 2, 2017.

[16] R. R. Hajar, "Implementasi Penjaminan Mutu Pendidikan Dalam Meningkatkan Kinerja Madrasah: Studi di MTs Assurur dan MTs Arrohmah Kota Tasikmalaya," J. Educ. Manag. Adm., vol. 1, no. 1, 2017.

[17] Rohmat, "Model Manajemen Mutu Madrasah Kajian di MIN \& MI Ma’rif Pageraji Purwokerto," JPA, vol. 19, no. 1, 2018. 